\title{
Surviving the Lunacy Act of 1890: English Psychiatrists and Professional Development during the Early Twentieth Century
}

\author{
AKINOBU TAKABAYASHI * \\ Department of Cultural History, Seisen University, Tokyo, Japan
}

\begin{abstract}
In recent decades, historians of English psychiatry have shifted their major concerns away from asylums and psychiatrists in the nineteenth century. This is also seen in the studies of twentieth-century psychiatry where historians have debated the rise of psychology, eugenics and community care. This shift in interest, however, does not indicate that English psychiatrists became passive and unimportant actors in the last century. In fact, they promoted Lunacy Law reform for a less asylum-dependent mode of psychiatry, with a strong emphasis on professional development. This paper illustrates the historical dynamics around the professional development of English psychiatry by employing Andrew Abbott's concept of professional development. Abbott redefines professional development as arising from both abstraction of professional knowledge and competition regarding professional jurisdiction. A profession, he suggests, develops through continuous re-formation of its occupational structure, mode of practice and political language in competing with other professional and non-professional forces. In early twentieth-century England, psychiatrists promoted professional development by framing political discourse, conducting a daily trade and promoting new legislation to defend their professional jurisdiction. This professional development story began with the Lunacy Act of 1890, which caused a professional crisis in psychiatry and led to inter-professional competition with non-psychiatric medical service providers. To this end, psychiatrists devised a new political rhetoric, 'early treatment of mental disorder', in their professional interests and succeeded in enacting the Mental Treatment Act of 1930, which re-instated psychiatrists as masters of English psychiatry.
\end{abstract}

Keywords: Professional development, English psychiatry, Andrew Abbott, Lunacy act of 1890, Early treatment of mental disorder

\footnotetext{
* Email address for correspondence: atakabayashi@nifty.com

I would like to thank archivists and librarians at the Wellcome Library, the London Metropolitan Archives, the Surrey History Centre and the Planned Environment Therapy Trust Archive. I would also like to express my gratitude to Professor Roger Cooter and Professor Akihito Suzuki, who have guided my study for many years. This work was supported by JSPS KAKENHI Grant Number JP26770261.
} 


\section{Introduction}

This paper revisits the profession of English psychiatry to explore its development in a relatively uncharted era: the early twentieth century. This interest of mine comes from the past historiography of English psychiatry. The profession of psychiatry was once a major target for researchers. Some studied it to understand the great past or the deplorable situations that were improved in later periods, ${ }^{1}$ while others explored psychiatry from the perspective of social history, under the influence of Michel Foucault. ${ }^{2}$ For example, Andrew Scull has written a number of seminal works that show how psychiatrists worked in lunatic asylums, and struggled for status, economic success and autonomy. ${ }^{3}$ However, Roy Porter and historians following in his wake have argued in important studies on the rise of nineteenth-century lunatic asylums that English psychiatry cannot be framed so strongly in terms of coercive motives of social control, a capitalistic social structure or professional interests in monopolising the psychiatric market. ${ }^{4}$ Such studies have estranged historians of psychiatry from the profession and they are also found in the studies of twentiethcentury English psychiatry. Historians such as Nikolas Rose and Matthew Thomson have discussed the rise of psychology as a marked phenomenon of the first part of the twentieth century, moving away from asylums, psychiatry and its profession..$^{5}$ Louise Westwood and Edgar Jones have focused on a new kind of site of psychiatric treatment: the former on a hospital for neurotic women, the latter on a research-oriented hospital for mental diseases. ${ }^{6}$ These studies show a shift in concern away from asylums and their doctors to other environments.

${ }^{1}$ William L1. Parry-Jones, The Trade in Lunacy: A Study of Private Madhouses in England in the Eighteenth and Nineteenth Centuries (London: Routledge and Kegan Paul, 1972); German E. Berrios and Hugh Freeman (eds), 150 years of British Psychiatry, 1841-1991 (London: Gaskell, 1991); German E. Berrios and Hugh Freeman (eds), 150 years of British Psychiatry, Vol. 2: The Aftermath (London and Atlantic Highlands, NJ: Athlone, 1996).

${ }^{2}$ Michel Foucault, History of Madness (London: Routledge, 2006).

3 Andrew Scull, Museums of Madness: The Social Organization of Insanity in Nineteenth-Century England (Allen Lane, 1979); Andrew Scull (ed.), Madhouses, Mad-doctors, and Madmen: The Social History of Psychiatry in the Victorian Era (London: Athlone Press, 1981); Andrew Scull, Social Order/Mental Disorder: Anglo-American Psychiatry in Historical Perspective (London: Routledge, 1989); Andrew Scull, Charlotte Mackenzie and Nicholas Hervey, Masters of Bedlam: The Transformation of the Mad-Doctoring Trade (Princeton, NJ: Princeton University Press, 1996); Jonathan Andrews and Andrew Scull, Undertaker of the Mind: John Munro and Mad-Doctoring in Eighteenth-Century England (Berkeley, CA: University of California Press, 2001).

${ }^{4}$ Roy Porter, Mind-forg'd Manacles: A History of Madness in England from the Restoration to the Regency (London: Athlone, 1987); Peter Bartlett, The Poor Law of Lunacy: The Administration of Pauper Lunatics in Mid-Nineteenth-Century England (London: Leicester University Press, 1999); Akihito Suzuki, 'Lunacy in Seventeenth- and Eighteenth-Century England: Analysis of Quarter Sessions Records', Parts I and II, History of Psychiatry, 2 (1991), 437-56 and 3 (1992), 29-44; Joseph Melling and Bill Forsythe, The Politics of Madness: The State, Insanity, and Society in England, 1845-1914 (London: Routledge, 2006); David Wright, 'Getting Out of the Asylum: Understanding the Confinement of the Insane in the Nineteenth Century', Social History of Medicine, 10 (1997), 137-55; Janet Oppenheim, Shattered Nerves: Doctors, Patients, and Depression in Victorian England (New York: Oxford University Press, 1991); Akihito Suzuki, Madness at Home: The Psychiatrist, the Patient, and the Family in England, 1820-1860 (Berkeley; London: California University Press, 2006).

${ }^{5}$ Nikolas Rose, The Psychological Complex: Psychology, Politics and Society in England, 1869-1939 (London: Routledge, 1985); Mathew Thomson, Psychological Subjects: Identity, Culture, and Health in Twentieth-Century Britain (Oxford: Oxford University Press, 2006).

${ }^{6}$ Louise Westwood, 'A Quiet Revolution in Brighton: Dr Helen Boyle's Pioneering Approach to Mental Health Care, 1899-1939', Social History of Medicine, 14 (2001), 439-57; Edgar Jones, Shahina Rahman and Robin Woolven, 'The Maudsley Hospital: Design and Strategic Direction, 1923-1939', Medical History, 51 (2007), 357-78. Also see Louise Westwood, 'Care in the Community of the Mentally Disordered: The Case of the Guardianship Society, 1900-1939’, Social History of Medicine, 20 (2007), 57-72. 
The shift in historians' concerns, however, does not legitimise ignorance of asylums and their doctors in the early twentieth century. In this period, asylums continued to increase their beds and patients, and more doctors joined the field of psychiatry. Meanwhile, psychiatrists were under pressure from opposition to private asylums and the stigma of pauperised public asylums. Such distress got worse after 1890. Importantly, asylums and psychiatrists devised their own strategies to develop their status and interests; asylums pursued commercial interests in their admission policies for institutional survival, while psychiatrists promoted a process of professional development to defend their living as doctors. As suggested in a recent volume of Medical History, historians of psychiatry who study the twentieth century should account for 'the development of value systems within each of these professional communities and programme groupings and for the changing patterns of interactions between professional groups, exploring not only the training regimes but also the patterns of recruitment into different professions' ${ }^{7}$

This paper focuses on the professional development of English psychiatry in the early twentieth century, but its narrative diverges from past studies of nineteenth-century psychiatrists that emphasised their monopoly and social control. Instead, it employs Andrew Abbot's conceptualisation to illuminate how English psychiatrists elaborated their survival strategy. ${ }^{8}$ Abbott developed a theory of professional development in the late 1980s, which was well received by Eric J. Engstrom. ${ }^{9}$ In the German case, Engstrom examined the competition between asylum-based and university-based psychiatrists, and argued that the latter won authority with theories of both prevention and somatic understanding of mental illness.

Abbott's theory of professional development emerged from previous sociological studies that had focused almost exclusively on professional organisation, knowledge and techniques. Instead, he argued that professions develop only when they succeed in abstracting knowledge and techniques, with evidence that some past professions failed to sustain their positions even though they were armed with specialised knowledge and techniques. ${ }^{10}$ This abstraction, which is equivalent to reduction in philosophy, may work well in the case of children's deviant behaviour. Abbott suggested that medical professions maintained that this behaviour was a medical matter of hypertension to bring it within their domain.

Around the abstraction, Abbott worked out several phases with a key term: jurisdiction. By 'jurisdiction', he meant 'the link between a profession and its work', though in effect he used the term to describe a virtual sphere in which a profession can monopolise or maximise material interest in particular clients. ${ }^{11}$ Professional development begins with disturbances in a professional jurisdiction, a situation in which the existing professional domain is shaken by external events and forces. ${ }^{12}$ Such jurisdictional chaos urges the existing profession to reconstruct its internal divisions of labour and workplace. ${ }^{13}$ Arranging the new professional structure and principles in work, the profession develops a

\footnotetext{
${ }^{7}$ John Turner, Rhodri Hayward, Katherine Angel, Bill Fulford, John Hall, Chris Millard and Mathew Thomson, 'The History of Mental Health Services in Modern England: Practitioner Memories and the Direction of Future Research', Medical History, 59 (2015), 622.

${ }^{8}$ Andrew Abbott, The System of Professions: An Essay on the Division of Expert Labour (Chicago, IL: University of Chicago Press, 1988).

${ }^{9}$ Eric J. Engstrom, Clinical Psychiatry in Imperial Germany: A History of Psychiatric Practice (Ithaca, NY: Cornell University Press, 2003).

${ }^{10}$ Abbott, op. cit. (note 8), 98-108.

11 Ibid., 20.

12 Ibid., 86-96.

13 Ibid., 79-85, 118-20, 125-9.
} 
jurisdictional claim to provide public legitimacy. ${ }^{14}$ In this phase, the successful profession does not fail abstraction but instead achieves legislation that gives sanction to the new professional structure and work style. ${ }^{15}$

Using Abbott's conception, this paper examines how English psychiatrists furthered professional development in the early twentieth century. In the first part, it outlines how late nineteenth-century legislation, specifically the Lunacy Act of 1890, undermined psychiatrists' jurisdiction in both personal career advancement and institutional settings. Secondly, it shows that psychiatrists devised countermeasures against the professional crisis by developing a new way of career-making and institutional management. The third part then deals with the law reform to institutionalise the countermeasures. To ensure their countermeasures were supported by the law, psychiatrists constructed a new legitimate discourse, 'early treatment of mental disorder', which was later embodied in the Mental Treatment Act of 1930.

Evidence is taken from diverse primary documents, which range from the register of the Medico-Psychological Association, mental hospital records, and papers of the Ministry of Health and Home Office to medical journals and popular newspapers. With these primary sources, this paper shows the overall picture of the professional development of English psychiatry in the early twentieth century.

\section{The Lunacy Act of 1890 and the Profession's Crisis}

\section{The Lunacy Act of 1890}

In 1889, Parliament imposed new legislation on psychiatrists and lunatic asylums under pressure from public anxieties about wrongful confinement, which was engendered by newspapers and journals between the $1860 \mathrm{~s}$ and $1880 \mathrm{~s} .{ }^{16}$ In particular, the case of a Mrs Weldon drove the public to demand legal safeguards from wrongful confinement. ${ }^{17}$ A politician sensitive to public opinion, the Lord Chancellor Lord Halsbury, Hardinge Stanley Giffard (1823-1921), exerted himself to enact a lunacy bill, ${ }^{18}$ and in 1889 had it passed as the Lunacy Amendment Act of 1889, which in 1890 was consolidated into the Lunacy Act. ${ }^{19}$

Significantly, the 1890 Act established legal control over psychiatric admissions of private patients. The preceding legislation, the Lunacy Act of 1845, required only two medical certificates signed by qualified medical doctors for admission to lunatic asylums, ${ }^{20}$ but the 1890 Act required an additional 'reception order', generally referred to as 'legal certification'. The new law stipulated that a justice of the peace specially appointed, a county court judge, or a magistrate having jurisdiction where the lunatic resided could issue legal certification for privately admitted patients. It also provided several conditional clauses concerning the procedure. For instance, Section 315, a penalty clause for those

\footnotetext{
14 Ibid., 59-79.

15 Ibid., 98-104.

16 Peter McCandless, 'Liberty and lunacy: the Victorians and wrongful confinement', in Andrew Scull (ed.), Madhouses, Mad-doctors, and Madmen, op. cit. (note 3), 339-62.

${ }^{17}$ With regard to the general history of lunacy and mental health laws, see Kathleen Jones, Asylums and After: A Revised History of the Mental Health Services from the Early 18th Century to the 1990s (London: Athlone, 1993); Clive Unsworth, The Politics of Mental Health Legislation (Oxford: Clarendon Press, 1987).

${ }^{18}$ Clive Unsworth has argued that the legal profession saw the scandals as an opportunity to undermine the professional ground of psychiatry (Unsworth, ibid., 83).

${ }^{19}$ Lunacy Act, 53, Victoria, 1890, ch. 5.

${ }^{20}$ On medical certificates of lunacy before 1889, see Peter Bartlett, 'Legal Madness in the Nineteenth Century', Social History of Medicine, 14 (2001), 107-31; David Wright, 'The Certification of Insanity in NineteenthCentury England and Wales', History of Psychiatry, 9 (1998), 267-90.
} 
who received psychiatric private patients without legal certification, stipulated a fine not exceeding $£ 50$ for illegal admission. These regulations were applied only to private, and not pauper, cases. The 1890 Act did not make major changes to the legal procedure for pauper lunatics; it succeeded the 1845 Lunacy Act that required a justice of the peace to issue a different order called a 'summary reception order' with a medical certificate.

In light of late nineteenth-century scandals, the 1890 Act also provided a clause to inhibit the further licensing of private asylums. In fact, legislators considered it desirable to abolish them completely, but immediate closure would require compensation for the existing institutions. Hence, they drew up a clause for gradual abolition.

The Act also introduced several provisions to prevent wrongful confinement. It guaranteed that patients had both extensive rights to appeal to the authorities and the right to appeal against the justices, magistrates and the Commissioners of Lunacy. It also granted the controlling authorities more power in asylum inspection, collection of asylum reports and patient discharge than before.

Overall, the 1890 Act marked a non-commercial, well-controlled and humane system of psychiatric admission, but this is not what it meant for contemporary psychiatrists. They thought the Act deprived them of their authoritative position in mental health services, particularly through the introduction of legal certification and suspension of licensing of new private asylums. The psychiatric profession was determined to challenge the new legislation that endangered their professional livelihoods.

\section{A Professional Crisis}

The 1890 Act caused a crisis for the psychiatric profession by undermining psychiatrists' livelihood as doctors, particularly in the private asylum business, the most profitable part of the psychiatric economy. In Abbott's conception, the Act was equivalent to a disturbance to professional jurisdiction. We rarely find documents that show how lucrative private asylums were, because they often disposed of records for reasons of privacy. However, the Royal Commission on Lunacy and Mental Disorder (1924-1926) reveals their profitability. It shows that some private asylum proprietors received salaries and extra bonuses in excess of $£ 2000$ annually between 1921 and $1923 .^{21}$ They derived this extravagant income from patients' payments: not just an expensive weekly maintenance rate, but also extra daily supplies, the latter amounting to an additional profit for the institutions of about $20 \%$. Provincial private asylums in England and Wales, which were maintained by 40 medical proprietors and 80 non-medical proprietors, annually earned $£ 400000$ in total. $^{22}$

The 1890 Act impeded such lucrative business in two ways. First, it discouraged prospective private patients and their families from applying for admission to private asylums because legal certification required them to involve the juridical bench whom they would usually approach only in criminal cases. For this reason, a significant number of patients were sent to illegal nursing homes. In the investigation into the violation of Section 315 of the 1890 Act, the Board of Control found that illegal nursing homes flourished. In the 1900s, it reported a case of a woman suffering from intermittent delusions whose family sent her to St. John's Nursing Institute, a private nursing home, in Upper Holloway in London. ${ }^{23}$ The lunacy law limited treatment for patients with delusions to registered

\footnotetext{
${ }^{21}$ Report of the Royal Commission on Lunacy and Mental Disorder (London: H.M.S.O., 1926), 133.

22 MH51/829: Royal Commission on Lunacy and Mental Disorders: Replies to questionnaire; provincial licensed houses, National Archives, Kew. $£ 400000$ in 1920 corresponds to approximately $£ 11300000$ in 2003, based on Jim O'Donoghue, Louise Goulding and Grahame Allen, 'Consumer Price Inflation since 1750', Economic Trends, 604 (2004), 38-46.

${ }^{23}$ MH51/71: Correspondence relating to alleged lunatics detained at R.D. Hurd's private asylum, Portland Grange, Matlock. No. 27206, 1902-09, National Archives, Kew.
} 
asylums and charitable hospitals, but her family admitted the woman to the illegal nursing home by pretending that she had only mild mental symptoms. Her family thought that it was humiliating to let her be certified legally as a lunatic. Interestingly, the patient's cousin remarked to the police that if he had his cousin certified as a lunatic, he would be blamed by other relatives, so the only option was to have 'taken her to some other place ... not had her certified'. ${ }^{24}$

The Board of Control also discovered the illegal reception of mental cases at private nursing homes in 1927, when Parliament enacted the Nursing Homes Registration Act. ${ }^{25}$ This Act, which aimed primarily at registration of private nursing homes, stipulated that it exempted from registration the nursing homes that received mentally ill patients under the 1890 Act and 1913 Mental Deficiency Act, because the Board of Control had already supervised them. Interestingly, however, a number of private nursing homes that received mental patients illegally contacted the Board of Control and local authorities voluntarily, because they were anxious as to whether they would be registered under the 1927 Act. $^{26}$ They unexpectedly disclosed the psychiatric black market.

Second, the 1890 Act steadily reduced the lucrative posts that the pre-1890 psychiatrists had enjoyed. While 82 private asylums accommodated 3035 private patients in 1889, only 54 continued to provide services for 2559 private patients in $1930 .{ }^{27}$ As a matter of course, the number of private asylum doctors also decreased. The reason for this decrease is so far unknown; presumably, private asylums could not find successors in their families and connections, or they no longer found the business sustainable. ${ }^{28}$ At any rate, contemporary psychiatrists considered this decline serious because private asylums provided a large part of their earnings, particularly in the case of senior psychiatrists. With the new legislation, they lost a lucrative aspect of their psychiatric career almost entirely.

In due course, psychiatrists were able to devise countermeasures to the professional crisis. They began by adapting their mode of institutional practice and career-making to new legislation.

\section{Changes in the Psychiatric Practice}

\section{The Rise of the Psychiatric Consulting Business}

In response to the professional crisis, the psychiatric profession challenged the 1890 Act by changing its mode of practice into one that fitted the new milieu. In Abbott's conception, this corresponds to a dimension in which a profession attempts to reconstruct its internal divisions of labour against a disturbance of jurisdiction. Since psychiatrists could no longer seek wealth through private asylums in the new legal setting, they devised another way in which they could retain access to their lucrative private practice: a consulting business, a mode of practice carried out by a practitioner for the wealthier class in society.

We can observe this change in the membership list of the Medico-Psychological Association (MPA), the professional association of English psychiatrists. The membership

\footnotetext{
${ }^{24}$ Ibid.

25 Nursing Homes Registration Act, George V, 1927, ch. 38.

${ }^{26}$ MH51/570: Nursing Homes Registration Act 1927, 1925-56, National Archives, Kew.

27 The data is taken from various kinds of statistics in The Annual Report of the Board of Control (London: H.M.S.O., 1930). In 1889, public asylums amounted to 66 county, borough and city asylums that provided treatment and care for 50709 patients, about $60 \%$ of the total of incarcerated psychiatric patients. In addition, Poor Law workhouses accommodated 17509 pauper patients, while single and home care provided for the rest. In 1930, 98 public asylums accommodated 119659 patients.

${ }^{28}$ Parry-Jones explained that the public asylums established after the 1845 Lunacy Act deprived private asylums of pauper lunatics, which contributed to the decrease of private asylums in the nineteenth century (Parry-Jones, op. cit. (note 1), 282).
} 


\begin{tabular}{lrrrr}
\hline & & & & \\
Occupational categories & \multicolumn{2}{c}{1890} & & \\
& No. & $\%$ & No. & $\%$ \\
& & & & \\
Consultant & 24 & 9.7 & 60 & 13.3 \\
Practitioner & 14 & 5.7 & 26 & 5.8 \\
Private asylum proprietor & 45 & 18.2 & 43 & 9.5 \\
Superintendent (private institutions) & 18 & 7.3 & 30 & 6.7 \\
Superintendent (public institutions) & 65 & 26.2 & 94 & 20.8 \\
Senior assistant medical officer & 19 & 7.7 & 80 & 17.7 \\
Assistant medical officer & 53 & 21.4 & 110 & 24.4 \\
Retired psychiatrists & 1 & 0.4 & 4 & 0.9 \\
Other & 9 & 3.6 & 4 & 0.9 \\
Total & 248 & & 451 &
\end{tabular}

Table 1: The occupational structure of English psychiatry. Source: Journal of Mental Science, 36 (1890); idem, 76 (1930); Medical Directory (London: Churchill, 1890); idem (1930).

Occupational categories

Consultant

Practitioner

Private asylum proprietor

Superintendent (private institutions)

Superintendent (public institutions)

Total
1890

No.

24

14

45

18

65

166
1930

No. $\%$

$60 \quad 23.7$

$26 \quad 10.2$

$43 \quad 17.0$

$30 \quad 11.8$

$94 \quad 37.1$

253

Table 2: The occupational structure of English psychiatry (senior class). Source: Journal of Mental Science, 36 (1890); idem, 76 (1930); Medical Directory (London: Churchill, 1890); idem (1930).

list annually attached to the Journal of Mental Science provides names, years of joining, and brief notes on each position for asylum doctors. Based on the list, this paper classifies psychiatrists' occupational positions into nine categories: (1) consultant, psychiatric practitioner who had high-profile experience as asylum superintendent; ${ }^{29}$ (2) practitioner, psychiatric practitioner who had experience only within the junior class of asylum doctors; (3) proprietor of private asylums; (4) medical superintendent of private asylums and charitable psychiatric hospitals; (5) medical superintendent of public asylums; (6) senior assistant medical officer; (7) assistant medical officer; (8) the retired; and (9) others. ${ }^{30}$ The data is from the 1890 and 1930 lists, which together show the process of reconstruction in the occupational structure of English psychiatry in the age of the 1890 Act.

The result suggests a steady increase in the number and percentage of consultants, as seen in Tables 1 and 2. Table 2 focuses on senior psychiatrists and shows this change with particular clarity. It illustrates that while private asylum proprietors decreased in proportion from 27.1 to $17.0 \%$, consultants increased from 14.4 to $23.7 \%$.

\footnotetext{
${ }^{29}$ Brian Abel-Smith explained that consulting doctors were established practitioners whose clients were from the upper and middle classes who could pay 'a guinea or more for each consultation or visit' (Brian Abel-Smith, The Hospitals, 1800-1948: A Study in Social Administration in England and Wales (London: Heinemann, 1964), 110.

30 This paper excludes the MPA members who never experienced asylum work.
} 
Most psychiatric consultants resided in London and Middlesex and had been public asylum superintendents. By 1914, they were swarming in Harley Street, Britain's most fashionable site for medical consultants: Robert Percy Smith (1853-1941) in Queen Anne Street, Thomas Claye Shaw (1846-1927) in Weymouth Street, Maurice Craig (1866-1935) in Welbeck Street, Theophilus Bulkeley Hyslop (1863-1933) in Portland Street, G. E. Shuttleworth (1840-1928) in New Cavendish Street, and Henry Rayner (1840-1926) and J. F. Woods (1856-1947) in Harley Street itself. ${ }^{31}$

Such newcomers from the field of psychiatry had to learn the traditional manner of practice in Harley Street: they had to secure positions at general hospitals if they wished to succeed in the consulting business. London's medical consultants did not wait silently for customers to come to their consulting rooms, but recruited potential customers in general hospitals where they served as charitable doctors free of charge. This gave them the opportunity to make personal connections with the wealthy class of society who often served as the hospitals' governors. Receiving only small honorariums from the hospital and practising sometimes perhaps only ostensibly for charitable reasons, consulting doctors encountered future customers. Also through general hospitals, medical consultants recruited middle-class patients who visited the outpatient departments. As Brian Abel-Smith argued long ago, in the latter half of the nineteenth century, hospital physicians and surgeons allegedly recruited patients who were originally seen by other general practitioners to their own private practices. ${ }^{32}$ This was called 'hospital abuse' or 'outpatient abuse'. ${ }^{33}$

Learning the rudiments of the consulting business, psychiatrists enthusiastically presented hospital governors with petitions for appointments. A forerunner was Henry Rayner, an elite psychiatrist who had been medical superintendent of the male section of the London County Council Asylum at Hanwell between 1872 and 1888, and became a consultant physician in Harley Street around 1890. In 1892, Rayner worked with hospital colleagues to open an outpatient department for the early treatment of psychiatric cases at St. Thomas's Hospital. ${ }^{34}$ Because of his personal and strong request to hospital authorities, in February 1893, the hospital decided to open an outpatient department for mental diseases. While giving weekly consultancies at the hospital, he built up his private practice in Harley Street and at Upper Terrace House in Hampstead, leaving behind $£ 41332$ when he died. ${ }^{35}$ This amount of money undoubtedly exceeded what ordinary public asylum doctors could earn in a lifetime. ${ }^{36}$

Rayner's was not an isolated case. Other psychiatric consultants also petitioned general hospitals for positions, and if successful, made a fortune. George Henry Savage (18421921) left behind $£ 27038$ when he died in 1921, Thomas Claye Shaw £53954 in

31 The data on psychiatrists' workplaces is taken from various volumes of Medical Directory (London: John Churchill).

32 Concerning consultants, see Chapters 6 and 10 in Brian Abel-Smith, op. cit. (note 29).

33 Keir Waddington, “Unsuitable Cases”: The Debate Over Outpatient Admissions, the Medical Profession and the Late-Victorian London Hospitals', Medical History, 42 (1998), 26-46. Also see Keir Waddington, Charity and the London Hospitals 1850-98 (Woodbridge; Rochester, NY: Royal Historical Society: Boydell Press, 2000).

34 H01/ST/K/10/046: Annual Report, 1878, St. Thomas's Hospital Papers, London Metropolitan Archives.

35 Probate Calendars, Probate Department of the Principal Registry Family Division.

36 The psychiatrists who had already become private asylum proprietors by 1890 left great fortunes: George Fielding Blandford (1829-1911), a proprietor of Munster House in Fulham, $£ 106785$; Alonzo Henry Stocker (1829-1910), proprietor of Peckham House in London, $£ 123993$ (Probate Calendars (note 35)). On the other hand, public asylum superintendents who devoted their career only to public asylums earned less: John Greig McDowall (1851-1906), medical superintendent of a county asylum in Yorkshire, £9493; D. G. Thomson (18571923), superintendent at a provincial county asylum, $£ 16883$ (idem). Please note, however, the probate records do not show the exact wealth they had made. The wealthier doctors increasingly created inter vivos trusts, because the tax rate rose throughout the early twentieth century. 
1927, Maurice Craig $£ 55066$ in 1935, Ernest William White (1851-1935) £34310 in 1935 and Bernard Hart (1879-1966) £67 168 in $1966 .{ }^{37}$ Most had experience as asylum superintendents in addition to running consulting offices around Harley Street in the age of the 1890 Act and obtaining general hospital appointments.

In general, however, psychiatrists suffered from employment stagnation. Apart from the above successful cases, most public asylum superintendents failed to become consultants before retirement because public asylums increased in number from 67 in 1890 to 98 in 1930. Accordingly, the number of junior psychiatrists also increased significantly, though they often gave up and quit asylum appointments altogether. Between 1890 and 1914, for example, 52 senior assistants and assistant asylum doctors left the MPA. ${ }^{38}$ Ultimately, only the upper class of psychiatrists benefited from the rise of psychiatric consultancy, a new occupational structure and mode of practice.

\section{Maurice Craig and His Consulting Practice}

In the age of the Lunacy Act of 1890, psychiatric consultants extended their network of private practice not only to general hospitals, but also to neurological hospitals and private asylums. In this period, as inter-institutional competition became fierce, these institutions faced difficulties filling their empty beds and resorted to psychiatric consultants who had grown into a hub in the psychiatric market. In return, however, consultants demanded financial rewards from the institutions. They admitted patients into a specific institution, whether psychiatric or neurological. After admission, they demanded the right of periodic consultation with the patient, almost akin to a middleman's fee, from the receiving institution. To follow Abbott's model, this section shows how the psychiatric profession reconstructed its workplace against a disturbance of jurisdiction.

Maurice Craig, one of the most eminent psychiatric consultants in the early twentieth century, is the focus here. ${ }^{39}$ He was a typical psychiatric consultant in the age of the 1890 Act; he had held a senior position in a lunatic asylum, successfully switched to a consulting business in central London and left behind a far greater fortune than public asylum doctors could make. He also played an important role in a Lunacy Law reform.

In climbing the career ladder, he attached himself to the Bethlem Royal Hospital, the nation's most celebrated institution of psychiatry, where he finally served as senior physician. His successful career can be attributed both to his family business of a private asylum in Bedford and to his educational career at Caius College, Cambridge. As a medical man who combined connections and intellect, he gained the lifetime support of his Bethlem colleagues. With such experience and connections, he began his private practice in Welbeck Street in London and, to stabilise the consulting business, he learned from what his senior psychiatrists invented. As his first step, he sought a connection with a general hospital. Succeeding George Savage, another leading psychiatrist who had been a Bethlem doctor, Craig became the physician for mental diseases at Guy's Hospital from 1903 to 1926. He also requested the hospital authorities to open a psychiatric outpatient facility, probably discontented that his position was honorary. ${ }^{40}$ This was approved in 1926.

Craig's consulting practice also expanded into private asylums. One of his targets was the Moorcroft House, a private asylum in London, where he served as the visiting physician. Private asylums usually expected the visiting physician to offer such nonpsychiatric services as surgery and dentistry that private asylum doctors did not specialise

37 Oxford DNB; Probate Calendars (note 35).

38 See the membership lists attached to Journal of Mental Science 36 (1890); 50 (1914).

${ }^{39}$ See the biography of Craig in G.H. Brown (ed.), Lives of the Fellows of the Royal College of Physicians of London (London: Royal College of Physicians, 1955), 474-5.

${ }^{40}$ H09/GY/A3/11/1: Hospital Committee Minutes, 1883-99, Guy's Hospital Papers, London Metropolitan Archives. 
in, though such was not the case as far as Craig was concerned. The Moorcroft counted on Craig to bring in wealthy patients and in return allowed him to provide an optional psychiatric service directly for inpatients whom he had introduced to the institution. In this way, he earned consulting fees, which was disclosed in a scandal in which Craig received $£ 100$ per consulting session, separate from the asylum fee. ${ }^{41}$

In the 1920s, Craig was named in several scandals reported by Truth, the late Henry Labouchere's radical weekly magazine. ${ }^{42}$ From the end of 1919 , it reported on a legal case in which a plaintiff sued psychiatrists for wrongful detention, the so-called Newington versus Holman case. ${ }^{43}$ The Holman family was well known in the shipping business and its younger scion, who suffered from mental illness, was directly involved in the affair. The patient originally suffered from pneumonia but developed mental symptoms in early 1916. His family sent him to Maurice Craig, who had become a famous psychiatric consultant at the time. Craig thought Holman's symptoms could be syphilitic and examined him using the Wassermann test. The result was positive. Accordingly, Holman was certified as a lunatic suffering from general paralysis of the insane (GPI) by two famous London-based consultant psychiatrists, Robert Percy Smith and J. G. Porter Phillips (1877-1946), both of whom had been Craig's colleagues at Bethlem. Finally, the patient was admitted to the Moorcroft House run by the Newington family in October 1916. An ordinary episode of GPI was said at that time to end with death in a few years, but Holman's condition did not take this course, which made him wonder about the reason for the asylum detention. In August 1918, Holman escaped and sued both Moorcroft and the above two certifying psychiatrists involved with his detention for their mistakes and the damage they had caused him. Holman did not bring action against Craig, but Truth criticised him for his conduct in receiving $£ 100$ per seasonal consulting session.

One may think this episode similar to older private asylum scandals, but it had an interesting secondary effect. Soon after Truth published an article about Holman's case, Hugh Munro, the proprietor of Riverhead House, a small private asylum in Kent, sent a letter to Truth. ${ }^{44}$ Munro denounced psychiatric consultants who benefited unjustifiably from private asylums. In making the charge, Munro even disclosed his intention of surrender the license of his private asylum, and in fact did so. ${ }^{45}$ According to Munro, his private asylum had 'a secret commission exacted by many of the specialists under the thinly veiled disguise of consultations'. ${ }^{46} \mathrm{He}$ explained:

If licensee does not pay these [consultation fees] himself or his petitioners to do so, he runs the risk of losing his clientele, if he pays them he loses his self-respect. My allegations in this respect are naturally difficult of proof, but I can assert (1) that a specialist cynically informed me two years ago that, if he sent me a patient prepared to pay more than eight guineas a week he would not be content with the usual commission on the first week's fees, but would visit such a patient quarterly, and expect to receive from me a cheque for thirteen guineas at each visit. (2) That a well known consultant, eleven days after placing a patient under my care, telephoned to know if it would be convenient for my patient to receive a professional visit from him the following Friday. After a brief and absolutely unnecessary visit, he claimed, and received, from me a cheque for ten guineas which, he said, was the sum always paid him by my predecessor under similar circumstances. ${ }^{47}$

${ }^{41}$ Truth, December 17 (1919), 1088-9.

42 With reference to Truth, see Gary Weber, 'Henry Labouchere, Truth and the New Journalism of Late Victorian Britain', Victorian Periodicals Review, 26 (1993), 36-43.

43 Truth (see note 41).

${ }^{44}$ Hugh Munro left little biographical information. No obituary was published upon his death in medical journals or popular newspapers. Information on his career is available instead in medical directories. After obtaining B.A. and M.A. at Oxford, he became assistant medical officer of the London County Council Asylum in Claybury, and served as senior assistant medical officer of the Maudsley Hospital. After the Great War, he succeeded the licensee of Tattlebury House in Goudhurst in Kent, renamed Riverhead House.

45 Annual Report of the Board of Control (London: H.M.S.O., 1919).

46 Truth, December 24 (1919), 1146-7.

47 Ibid. 
This letter shows that psychiatric consultants played a dominant role in terms of their business relationships with private asylum proprietors. For private asylums, they were simply a source of clientele.

Craig also reached out to neurological institutions. In the 1920s, he had strong connections with the Cassel Hospital for Functional Nervous Diseases located in Richmond. In this institution, Craig served as a consulting physician and as a member of the general committee, financial committee and house committee. The Cassel Hospital was established in 1919 with a donation of $£ 225000$ by Ernest Cassel (1852-1921), a successful merchant banker and financier. ${ }^{48}$ It intended to provide sixty beds for patients who suffered from war neurosis and associated nervous disorders, but soon found it difficult to maintain enough patients to meet with philanthropic success. ${ }^{49}$ This was partly because the superintendent, Thomas Arthur Ross (1875-1941), was an unknown doctor in the medical world. Hence, the Cassel Hospital invited seven eminent consulting physicians specialising in neurology and psychiatry to its managerial board: Farquhar Buzzard (18711945), Henry Head (1861-1940), Arthur Frederick Hurst (1879-1944), Frederick Treves (1853-1923), Lord Dawson of Penn (1864-1945), Bernard Hart and Maurice Craig. The hospital expected them, as Munro did Craig, to refer their patients to the institution.

As a matter of course, the above-mentioned consultants did not intend to work voluntarily for Cassel. Rather, they expected they would extend their consulting practice through their hospital roles, which is clearly shown in the minutes of the Medical Committee. In June 1921, Craig, Buzzard, Head and Ross discussed in the Medical Committee whether the hospital should allow private consultancy for inpatients. ${ }^{50}$ Behind this argument was Ross's discontent with the existing situation in which he was not allowed to offer private consultancy at the hospital. Contrary to Ross's aspiration, however, the Hospital's General and House Committee officially decided in July that if patients wished to have therapeutic consulting sessions, they could seek them with a charge of ten guineas per session. ${ }^{51}$ Ross was of course not content with this decision and continued his discussion in the Medical Committee. In December 1922, they finally reached an agreement that the hospital would allow Ross to provide personal consultation to inpatients at the hospital if their family doctors were willing. ${ }^{52}$ With this permission, Ross could provide optional treatment for Cassel's patients at a maximum rate of $£ 22$ s. (two guineas) per session.

This example of institutional politics is unique. According to the agreement, Ross could provide consultancy for patients only when the original family doctors approved. However, many of them were admitted to the hospital with recommendations of the above-named consulting doctors. That is, such consulting doctors would not allow Ross to provide consultancy to their own patients. Hence, the agreement meant that while Ross could provide consulting sessions to a limited range of the patients, consulting doctors defended their rights to provide private consultancy for the inpatients whom they had introduced to the hospital.

Significantly, Maurice Craig was the most active doctor in the Medical Committee. He attended the committee far more frequently than the other consulting doctors and committed himself to all the above decisions concerning consulting practices. Both Craig

\footnotetext{
48 'Sir Ernest Cassel: Maker of a Great Fortune', The Times, 42833, 1921, 5.

${ }^{49}$ Annual Report of the Cassel Hospital for Functional Nervous Diseases (1926), Planned Environment Therapy Trust Archive.

${ }^{50}$ Medical Committee Minutes, 22 June 1922, Cassel Hospital Papers, Planned Environment Therapy Trust Archive.

${ }^{51}$ General and House Committee Minutes, 6 July 1921, Cassel Hospital Papers.

52 Medical Committee Minutes, 14 December 1922, Cassel Hospital Papers.
} 
and Cassel's hospital governors wished him to be involved with hospital administration, as the governors needed Craig to recruit new patients. In July 1921, they asked Craig to submit the names of wealthier patients whom he knew, which shows that they shared a mutually advantageous relationship. ${ }^{53}$

Other psychiatric consultants also extended their practice by approaching neurological hospitals, such as Thomas Outterson Wood (1843-1930) and Fletcher Beach (1845-1929) at the West End Hospital for Nervous Diseases, and Edward Mapother (1881-1940) at the Maida Vale Hospital for Nervous Diseases. By providing private consultancy for inpatients of neurological hospitals, psychiatric consultants secured their income in the age of the 1890 Act.

Alongside the rise of psychiatric consultancy, doctors who specialised in psychoanalysis occupied only a marginal portion of private practice in the field of mental illness. Psychoanalysis does not need inpatient facilities in most cases; its therapeutics requires a couch and outpatient room. However, early twentieth-century psychoanalytic doctors needed those, because not all patients could visit their clinics periodically and their symptoms would worsen beyond the reach of family care. Nevertheless, psychoanalytic doctors had few connections with inpatient institutions to which they could transfer patients with serious mental illness from their clinics. What is worse, they could not open their own inpatient institutions because the 1890 Act prohibited just that.

Hugh Crichton-Miller (1877-1959), for example, a founder of the Tavistock Clinic opened in 1920, attempted to resort to private practice for his earnings because the Tavistock Clinic was a philanthropic enterprise. ${ }^{54}$ However, he soon faced difficulties in some cases where patients' symptoms worsened. According to the 1890 Act, serious mental cases were to be sent immediately to lunatic asylums, which meant patients went away from Crichton-Miller's treatment. For this reason, in 1928, Crichton-Miller asked the Board of Control to allow him to establish a small private institution to receive ten cases of serious mental illness. ${ }^{55}$ The response was, understandably, negative. CrichtonMiller's case does not represent all psychoanalytic practices, but indirectly shows that psychoanalysis and its advocates hardly occupied a significant position in private practices of mental health in the age of the 1890 Act.

However, neurologists played a significant role in the post-1890 psychiatric market. They were interested primarily in physiological aspects of the nerve rather than pathological ones. However, they did see mild mental cases in their private clinics. It is not easy to explore their actual practices because they rarely left documents related to private practice. Instead, psychiatrists' utterances show they were cautious about those working in the field of neurology, a closely linked field. In 1915, George Henry Savage, a leading consulting psychiatrist, criticised neurologists for providing less effective treatment for mild and acute cases of mental disorder, especially the prescription of 'routine rest cures and travelling' ${ }^{56}$ His intention was to emphasise his rivals' incompetency in therapeutics. Such criticisms often appeared in medical journals in the early twentieth century, which shows the significant presence of neurologists in the psychiatric market. ${ }^{57}$

\footnotetext{
53 Medical Committee Minutes, 6 July 1921, Cassel Hospital Papers.

54 Suzanne Raitt, 'Early English Psychoanalysis and the Medico-Psychological Clinic', History Workshop Journal, 58 (2004), 71.

55 MH51/287: Application for approval of Nursing Home under Mental Treatment Act, 1930: Dr M.M. Lilley, Oxhey Grove, Hatch End, Middlesex, 1928-37. In 1930, Josephine Miller, a daughter of Hugh Crichton-Miller, also sent a letter to the Board of Control, in which she asked for permission to receive serious mental cases. The Board of Control did not approve her suggestion.

56 George H. Savage, 'Hospital Treatment v. Lunacy Treatment', The Lancet, 186, 4796 (1915), 250.

${ }^{57}$ For example, see Lionel A. Weathery, 'Incipient Mental Diseases', The Lancet, 194, 5004 (1919), 174; Lionel A Weatherly, A Plea for the Insane: The Case for Reform in the Care and Treatment of Mental Disease (London: Grant Richards, 1918), 129-31.
} 
It is important to remember, though, that medical consulting businesses for hysteria and neurasthenia, milder forms of mental disorder, had already developed from the late nineteenth century onwards. As Janet Oppenheim has argued, by the late nineteenth century, 'certain psychiatrists could function solely as consultants in case of mental disorder, whether mild or acute, and they accordingly sought a clientele among the prosperous reaches of society'. ${ }^{5}$ However, as Tables 1 and 2 show, the consulting practice was relatively underdeveloped in the late nineteenth century. It was not until the early twentieth century, as Maurice Craig's consulting practice illustrates, that more psychiatrists began participating in the consulting market.

\section{The Holloway Sanatorium and Institutional Survival}

In both personal medical practices and institutional settings, psychiatrists came up with new measures to survive the 1890 Act. Because of legal certification, patients and their families tended to avoid lunatic asylums and hospitals for the insane, and instead resorted to institutions such as nursing homes, foreign hostels and hydropathic institutions. In the professional crisis under the 1890 Act, psychiatric institutions developed three strategies to re-attract customers: using the voluntary admission system without legal certification, keeping high-paying patients from being discharged, and decreasing charitable and publicly funded admissions.

Voluntary admission originated with the Lunatics Act Amendment Act of 1862. ${ }^{59}$ This legislation granted power to private asylums and charitable hospitals for the insane to admit those who were 'not insane' but were 'conscious of a want of power of self-control'. ${ }^{60}$ It did not require the invalids to commit themselves to any legal and medical formality, and technically named them 'voluntary boarders'. However, both doctors and patients rarely employed voluntary admission before 1890 because the 1862 Act limited voluntary boarders to those who had been lunatics at asylums in the preceding five years. ${ }^{61}$

After 1890, psychiatrists and institutional managers recognised the value of voluntary admission. The 1890 Act abolished the above-mentioned limitation and instead prescribed that any person whose symptoms were not serious enough to be certified could be admitted to psychiatric institutions without legal formalities. Psychiatrists and institutional managers increasingly employed this admission system to attract wealthy clients who were anxious about the legal procedure. Consequently, voluntary boarders increased from 119 in $1891,9 \%$ of total admissions to private and charitable mental hospitals, to 1343 in 1930 , or $48 \% .^{62}$

The success of voluntary admissions relied upon several eminent charitable hospitals for mental diseases, such as the Bethlem Royal Hospital, Manchester Lunatic Hospital and the Holloway Sanatorium. These institutions occupied between $50 \%$ and $60 \%$ of total voluntary admissions, to which the Holloway Sanatorium contributed most.

The Holloway Sanatorium was a charitable psychiatric hospital located in Virginia Water, Surrey, established by a legacy from Thomas Holloway (1800-83), the manufacturer

\footnotetext{
58 Janet Oppenheim, op. cit. (note 4), 26.

${ }^{59}$ Lunatics Act Amendment Act, 25\&26, Victoria, 1862, ch. 111.

${ }^{60}$ Annual Report of the Commissioners in Lunacy (London: H.M.S.O., 1863), 12-13; 'Medical News', The Lancet, 82, 2079 (1863), p. 25.

${ }^{61}$ William L1. Parry-Jones pointed out that this clause made voluntary admission somewhat paradoxical, because the less legalistic admission system was provided only for those who already had been involved with the legal procedure of lunacy (Parry-Jones, op. cit. (note 1), 25).

62 These figures are taken from various statistics of Annual Report of the Board of Control (London: H.M.S.O.).
} 
of patent medicines. ${ }^{63}$ Holloway and his relatives regarded this hospital as one of his major philanthropic activities. They spent $£ 252198$ on its establishment, and in 1893 held an opening ceremony with the Prince and Princess of Wales in attendance. ${ }^{64}$

Despite its charitable nature, the Holloway Sanatorium was inclined towards commercial interests from the beginning. While spending the above-mentioned amount of Holloway's legacy on its establishment, it was not competent to collect subscriptions and endowments from the public. Accordingly, it soon depended on fees from patients for $99 \%$ of its annual income, ${ }^{65}$ and sought ways to improve profitability. The answer was found in voluntary admission.

In promoting voluntary admission, the Holloway Sanatorium emphasised its therapeutic and humanitarian values. The superintendent, Sutherland Rees Philipps, who had previously served as medical superintendent at the Wonford House Hospital in Exeter, argued around 1891 that legal certification caused 'the person who comes under its provision to be treated as accused of a crime instead of suffering from a disease and to easily become a chronic inmate of mental health institutions' ${ }^{66}$ With voluntary admission, however, 'the patient comes under treatment at an earlier and more curable stage of his disorder. In two out of three cases, he goes out well. He has not been deprived of his liberty, and his prospects have not been damaged by the stigma that too often fastened itself to the certified patient. ${ }^{67}$

However, this flowery logic turned out to be untrue. A public scandal between 1894 and 1895, again uncovered by Truth, revealed that the institution developed the voluntary admission system for commercial reasons. Truth commenced its campaign with the story of a male patient named Thomas Weir, who had died at the hospital as the result of lengthy physical restraint. ${ }^{68}$ It accused the hospital of being responsible for Weir's death, claiming that the hospital cared for him inadequately to cut down expenses. The Lunacy Commissioners found this allegation true in a subsequent official investigation. ${ }^{69}$

However, the scandal did not end with Weir's case. Truth disclosed that the institution had abused voluntary admission for commercial reasons. ${ }^{70}$ As shown above, the Holloway Sanatorium regarded voluntary admission as attractive for patients who shunned the status of lunatics and of being legally certified. In consideration of this advantage, Truth revealed, the Sanatorium schemed to not only increase voluntary admissions, but also to keep these patients from leaving, especially in the case of high-paying patients. It specifically invented a special technique in management, which changed the legal status of voluntary boarders to that of lunatics without taking consent from patients and their families. ${ }^{71}$ Under the new status, ex-voluntary-boarders could no longer be discharged without the hospital's consent.

63 Oxford DNB; Anthony Harrison-Barbet, Thomas Holloway: Victorian Philanthropist a Biographical Essay (Egham: Royal Holloway, University of London, 1994), 21-42; Anon., The Story of Thomas Holloway (1800-83) (Glasgow: Robert Maclehouse, 1933).

64 2620/1/1: Minutes of Annual and Ordinary Meetings of the General Committee, 1886-1915, Holloway Sanatorium Papers: Surrey History Centre. Thomas Holloway’s wealth at death was $£ 596335$ 8s. 5d (Oxford $D N B)$.

65 2620/1/1, ibid.; 2620/1/4: Annual Reports nos 16-20, 1906-10, Holloway Sanatorium Papers; 2620/1/9: Annual Reports, loose copies: no 29, dated 1914; nos 42-9, dated 1927-34; nos 51-62, dated 1936-47; and copies marked as proofs, dated 1932, 1938 and 1941, Holloway Sanatorium Papers.

66 2620/1/1, op. cit (note 64).

67 Ibid.

${ }^{68}$ Truth, January 24 (1895), 210.

69 Annual Report of the Commissioners in Lunacy (London: H.M.S.O., 1895), 118-24.

${ }^{70}$ Truth, September 12 (1895), 612.

${ }^{71}$ Ibid. 
In this transfer, Truth reported, the Holloway Sanatorium employed an artifice to avoid violation of the law. The 1890 Act stipulated that spouses and relatives should present a petition for admission, 'if possible' ${ }^{72}$ The Holloway Sanatorium, however, avoided doing so by writing up the application without involvement from patients' families. ${ }^{73}$ The Act also stipulated that an application for admission should be accompanied with two medical certificates of lunacy, which should be signed by doctors who were not on the staff of the institution receiving the patient and did not have any financial interest in the institution. To avoid violating this regulation, the Holloway Sanatorium forced a male voluntary boarder, who had medical qualification, to sign a medical certificate of lunacy for other voluntary boarders. ${ }^{74}$ It was a clever evasion of the law since the Holloway could legitimise this by saying he had no financial interest in the hospital, nor the hospital staff. On such legal grounds, the Holloway kept him after recovery to write medical certificates of lunacy for twenty-five voluntary boarders.

This was not a mere allegation; Truth had many reliable inside informants. Regarding the admitted doctor, indeed, the Commissioners in Lunacy confirmed in their own investigation that he signed exactly twenty-five medical certificates of lunacy. ${ }^{75}$ They also found that the Holloway admitted a number of voluntary boarders who showed certifiable symptoms but had not yet been certified. ${ }^{76}$

Along with such idiosyncratic management, the Holloway Sanatorium intensified its commercial efforts by decreasing charity admissions and giving preference to high-paying patients. It gradually decreased new admissions from 162 in 1886 to 41 in 1930, and stopped free admissions by the early $1900 \mathrm{~s} .{ }^{77}$ Superintendent William D. Moore explained in 1902 that the institution could not find proper charitable cases 'where the social status was sufficient, and where there was a reasonable hope of recovery or amelioration'. ${ }^{78}$ Behind such an excuse, interestingly, the institution earned a surplus of $£ 9400$ in that year. ${ }^{79}$ This fact shows that the Holloway improved its profitability per patient, both by keeping high-paying patients and by forsaking those who sought charity. In 1886, when the annual average number of resident inmates was 156, the institution earned $£ 77$ per patient, but earned $£ 326$ per patient in $1930 .{ }^{80}$ Accordingly, it had annual surpluses of between $£ 6000$ and $£ 11000$ from the 1910s.

The profit-making nature arose from the fact that the institution did not have any specific financial resources after having spent Thomas Holloway's legacy on its establishment. For this reason, the hospital governors were constantly worried about finances. In 1901, for instance, the Annual Report admitted 'the importance, in the absence of endowment, of having a number of richer patients in order to secure funds' ${ }^{81}$ As such, the Holloway resorted to a commercial mode of practice to survive in the medical market under the 1890 Act.

There is no conclusive evidence that the Holloway Sanatorium was an isolated case. Throughout the age of the 1890 Act, the Commissioners in Lunacy and the Board of Control reported that several psychiatric institutions, including private asylums

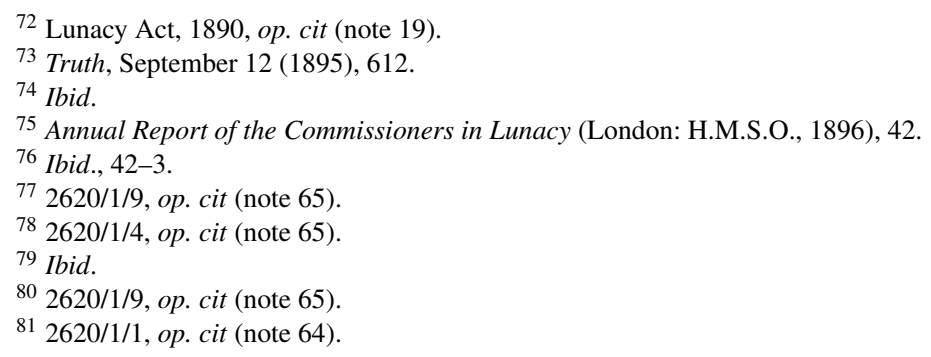


and charitable hospitals for insanity, admitted certifiable patients as voluntary borders, changed the status of some to lunatics, decreased charitable admissions and improved profitability. ${ }^{82}$ Even the Bethlem Royal Hospital, which had a vast amount of financial resources for charity, decreased the percentage of charitable cases from $100 \%$ in 1882 to $34 \%$ in $1928 .{ }^{83}$ Under the 1890 Act, psychiatric institutions had no choice but to seek commercial interests for survival.

\section{Psychiatrists and Political Language}

\section{The Making of 'Early Treatment of Mental Disorder'}

In developing practical countermeasures to the 1890 Lunacy Act, psychiatrists waged a political war. They aspired to establish a new legal order suited to the new mode of practice in the age of the 1890 Act. In so doing, however, they noticed that they could hardly repeal the law simply by offering opposition. Accordingly, they mobilised a political discourse to persuade legislators and the public about 'early treatment of mental disorder', as part of which they introduced several concepts not inherent in psychiatric terminology: humanitarianism, heroism, poor law reform and national efficiency.

This section deals with the final part of Abbott's conception of professional development: jurisdictional claim and jurisdictional settlement. It shows how a profession constructs a self-interested political claim by abstracting its specialised knowledge, and how a profession achieves new legislation that would legitimise a new mode of internal division of labour and workplace.

In the early 1890s, Robert Percy Smith, resident physician of the Bethlem Royal Hospital, began to refer to humanitarian reasons for new legislation, particularly criticising legal certification and its inhumane effects. ${ }^{84}$ Smith believed legal certification produced a psychologically deteriorating effect on patients and their relatives based on his experience at Bethlem. According to Smith, patients' relatives would feel as though they had been 'sentenced to something' and 'made a pauper lunatic' when visiting a magistrate to gain his signature on the application for admission to the hospital. ${ }^{85}$ This psychological distress had 'added to the patients' misery'. ${ }^{86}$

Henry Rayner, medical superintendent of the London County Council Asylum at Hanwell and lecturer on mental disease at St. Thomas' Hospital, developed Smith's humanitarian cause into a therapeutic cause. In 1896, he argued at the Annual Meeting of the British Medical Association that legal certification caused a delay in treatment by deterring patients' relatives, especially the early and mild cases, from seeking asylum treatment. ${ }^{87}$ In early cases, patients' relatives tended to avoid asylums due to the notorious legal certification, which often resulted in the deprivation of specialist treatment at the

\footnotetext{
82 Annual Report of the Commissioners in Lunacy (London: H.M.S.O., 1896), 54-5; Annual Report of the Commissioners in Lunacy (London: H.M.S.O.,1906), 52; Annual Report of the Board of Control (London: H.M.S.O., 1922), 28; Annual Report of the Board of Control (London: H.M.S.O., 1929), 10-11. Also see 'Medicine and the Law', The Lancet, 200, 5159 (1922), 148 and 'Medicine and the Law', The Lancet, 200, 5181 (1922), 1298-9.

${ }^{83}$ MH51/350: Registered Hospitals: Extent of their use for charitable purposes, National Archives, Kew.

${ }^{84}$ R. Percy Smith, 'Correspondence: The Working of the New Lunacy Act', British Medical Journal, 2,1542 (1890), 178; R. Percy Smith, 'The Working of the New Lunacy Act', Journal of Mental Science, 36, 155 (1890), 597-99.

85 R. Percy Smith, 'Defects in the Working of the Lunacy Act, 1890', Journal of Mental Science, 37, 156 (1891), 61-2.

86 Ibid.

87 'Sixty-Fourth Annual Meeting of the British Medical Association', British Medical Journal, 2, 1865 (1896), $797-827$.
} 
stage at which a patient's symptoms were most curable. On this basis, he proposed new legislation for 'early treatment of mental disorder' where legal certification was no longer required.

'Early treatment of mental disorder' was not an entirely new idea in English psychiatry. John Bucknill, for example, proposed the promotion of early and preventive treatment of mental disorder in 1880 to increase the rate of cured cases. ${ }^{88}$ However, his claim was not well received before 1890 , presumably because psychiatrists became desperate due to the increase of asylum inmates in the late nineteenth century, or because the theory of degeneration was convincing in explaining why insanity increased. The legal certification and following professional crisis triggered an upsurge of "early treatment of mental disorder' at the turn of the twentieth century.

In the early twentieth century, Scottish psychiatrists introduced the language of poor law reform to the discourse on early psychiatric treatment. In 1902, John Sibbald, an eminent Scottish psychiatrist, presented a paper at a special meeting of the Edinburgh MedicoChirurgical Society to highlight the necessity for early psychiatric treatment in Scotland. ${ }^{89}$ In the same way as Rayner, he identified legal intervention as 'an important defect' in the treatment of mental diseases and suggested the establishment of a special ward at the Royal Edinburgh Infirmary for 'treatment of incipient and transitory mental disorder'. Significantly, in the discussion on Sibbald's speech, Scottish fellows applied a particular expression to the psychological detriment caused by legal intervention: 'stigma', a term used almost exclusively in poor law reform around the turn of the twentieth century. ${ }^{90}$ The poor law reformers employed this term to refer to a case in which deterrent welfare legislation, especially the New Poor Law of 1834, degraded its recipients and led them into inescapable distress. ${ }^{91}$

The English counterpart no sooner borrowed 'stigma' than medical journals reported the Scottish reference. At the meeting of the Medico-Psychological Association in 1902, an eminent neurologist, William Gowers, read a paper on the Lunacy Law reform in England and claimed that the 1890 Act compelled patients to face 'the same course, the same stigma, the same distressing processes' as incurable and pauper cases. ${ }^{92}$ From then on, English psychiatrists employed the word 'stigma' in the discourse of psychiatric early treatment.

In the meantime, Gowers suggested a rather bold measure to fight psychiatric stigma: to deliberately violate Section 315 of the 1890 Act, which prohibited any doctor from receiving psychiatric patients without legal certification. Gowers remarked:

I arranged a course which was clearly contrary to the law. I sent the patient with his wife to a medical man who received them into his house for payment. What was the result of thus breaking the law? In a fortnight he was well; the delusion was gone. ... In this case ... it [certification] would have been purely harmful; it might have destroyed the prospect of recovery and certainly would have delayed improvement. ${ }^{93}$

Interestingly, no doctor accused Gowers of flaunting the Lunacy Act. Rather, William Broadbent (1865-1946), the Physician in Ordinary to the Queen, defended Gowers, remarking that doctors should remember that 'even if he [a patient] gets well his self-respect is wounded for ever, that he can never lift up his head again in

88 J.C. Bucknill, The Care of the Insane and their Legal Control (London: Macmillan, 1880), 38.

${ }^{89}$ John Sibbald, 'The Treatment of Incipient Mental Disorder and its Clinical Teaching in the Wards of General Hospitals', Journal of Mental Science, 48, 201 (1902), 215-26.

90 'The Proposed Psychiatric Clinique in Edinburgh', Journal of Mental Science, 48, 201 (1902), 382.

${ }^{91}$ Paul Spicker, Stigma and Social Welfare (Croom Helm: St. Martin, 1984), 16-7.

92 'An Address on Lunacy and the Law', The Lancet, 160, 4134 (1902), 1369.

${ }^{93}$ Ibid., 1370. 
society' ${ }^{94}$ His remarks show that the stigma of lunacy was a matter of personal self-respect and individual autonomy in society, which was endangered by unreasonable labelling. In this regard, Gowers' humanitarianism seems to fit well in medical humanitarianism rooted historically in the Enlightenment.

Psychiatrists also employed the concept of 'national efficiency', a politico-economic concept popular in the early twentieth century. With this concept, political ideologues argued that Britain needed administrative machinery in which the state, industry, professions and labour all worked together efficiently in the military and economic contests with Germany and the United States. ${ }^{95}$ In medicine, preventive medicine embodied 'national efficiency'. To appeal to contemporary liberal and socialist legislators, psychiatrists employed this language in their own political discourse.

Robert Armstrong-Jones, medical superintendent of the London County Council Asylum of Claybury from 1893 to 1916, played an important role in developing the discourse on 'national efficiency' in Lunacy Law reform. He raised the issue of psychiatric early treatment at a meeting of the Medico-Legal Society in late 1913, and stated it was 'of immense importance to the community, both from the point of view of prevention as well as finance' ${ }^{96} \mathrm{He}$ continuously laid emphasis on this point:

What we urgently need, not only for the sake of patient, not only for the sake of his relatives, but for the sake of humanity, and for the sake of true economy, is greater elasticity to treat the early symptoms of this disease, to treat them during the stages when an accurate diagnosis may not yet be possible, and before the disease has become chronic. ${ }^{97}$

To substantiate this claim, he particularly referred to puerperal insanity, a complicated mental symptom arising from an infectious disease after giving birth. He explained that the invalid mother had to face the 'stigma' of legal certification in psychiatric treatment, which 'will not only stamp her as an outcast among her family, but will also cast a permanent blemish upon her children, and their future chances in life will also be prejudiced'.$^{98}$ In short, he emphasised the misery of mothers who were stigmatised by the lunacy law despite the physical origins of their symptoms. Armstrong-Jones' reference to a mother's health was an obvious choice, because contemporary legislators believed the prevention of ill health in mothers was key to national efficiency. ${ }^{99}$ Thus, Armstrong-Jones most likely intended to refer to puerperal insanity to legitimise 'early treatment of mental disorder'.

Lobbying with such logic and rhetoric, Armstrong-Jones insisted upon the economic and humanitarian importance of psychiatric early treatment. He likened it to a 'Magna Carta of every person likely to suffer from nervous stress and breakdown', saying that ' 80 per cent of the population should be certified' if the bill was not enacted. ${ }^{100}$ Because of these political efforts, 'early treatment of mental disorders' became a big issue not only in psychiatry, but also in politics.

\footnotetext{
94 'The Medico-Psychological Association of Great Britain and Ireland', Journal of Mental Science, 49, 204 (1903), 195.

95 See G.R. Searle, The Quest for National Efficiency: A Study in British Politics and Political Thought, 1899 1914 (Oxford: Blackwell, 1971).

96 Robert Armstrong-Jones, 'The Rational Treatment of Incipient Insanity and the Urgent Need for Legislation', Transactions of the Medico-Legal Society, 8 (1914), 22.

97 Ibid., 32.

98 Ibid., 25-6.

99 See Chapter 3 in Pat Thane, The Foundations of the Welfare State (London and New York: Longman, 1982).

100 'A Proposed Bill Relating to Incipient Mental Disorder', British Medical Journal, 2, 2792 (1914), 27.
} 


\section{'Early Treatment of Mental Disorder' in the War and Interwar Period}

In the pre-war period, psychiatrists failed to establish new legislation. They campaigned for Lunacy Law reform patiently and relentlessly, but their reform bills ended in failure six times between 1890 and 1914. ${ }^{101}$ They persuaded the Lord Chancellor and the AttorneyGeneral to introduce a reform bill, but failed to persuade Members of Parliament (MPs) of its necessity. Politicians responded either that the House of Commons should avoid 'contentious' bills ${ }^{102}$ or that it must reject the bill for 'want of time' and 'pressure of business' in Parliament. ${ }^{103}$

However, the Great War changed the political landscape around psychiatry with the great incidence of shell shock on the Western Front. ${ }^{104}$ Shell shock had a great impact on not only the army, but also, more importantly, on psychiatrists and their politics, as it seemingly offered legitimacy to their political claim of 'early treatment of mental disorder'. 105

In earlier parts of the war, the army and wartime government found it difficult to extend medical provisions to shell shock. Initially, the army provided special beds for returning shell-shocked cases by converting lunatic asylums into military hospitals. By July 1917, such conversions amounted to 27000 beds in 21 military psychiatry institutions. ${ }^{106}$ In addition, neurological wards were established in general military hospitals. ${ }^{107}$ However, the army had to carry invalid soldiers who could not recover for several months in the military institution, thence discharging and admitting them to lunatic asylums as ordinary lunatics, which meant that the legal certification of lunacy stigmatised soldiers who had been respectable citizens in peacetime. The government understood that about 6700 shellshocked soldiers were accommodated in asylums in $1916 .{ }^{108}$

In early 1915, some MPs learned of this situation from local sources, and objected to the detention of shell-shocked soldiers in lunatic asylums. They demanded non-asylum, non-

${ }^{101}$ A bill intituled an act to amend the lunacy acts, Twentieth-Century House of Commons Sessional Papers, Bills, 1897, 329; A bill intituled an act to amend the lunacy acts, Twentieth-Century House of Commons Sessional Papers, Bills 1898, 298; A bill intituled an act to amend the lunacy acts, Twentieth-Century House of Commons Sessional Papers, Bills 1899, 225; A bill intituled an act to amend the lunacy acts, TwentiethCentury House of Commons Sessional Papers, Bills 1900, 119; A bill to amend the Lunacy Acts, TwentiethCentury House of Commons Sessional Papers, Bills 1904, 210. These bills are contained in House of Commons Parliamentary Papers Online. The bill submitted in 1914 is not contained in this collection, perhaps because the Great War began just after the introduction. It is confirmed from the following archival material that the bill was actually drafted and introduced (HL/PO/JO/10/10/561, Parliamentary Archives, 1914).

102 Parliamentary Debates, House of Commons, 51 (1897), 1373; idem, 73 (1899), 455; idem, 139 (1904), 281-82; idem, 1084.

103 'Delayed Lunacy Legislation', Journal of Mental Science, 55, 230 (1909), 523.

104 Concerning the history of shell shock, see Peter Leese, Shell Shock: Traumatic Neurosis and the British Soldiers of the First World War (Basingstoke: Palgrave Macmillan, 2002); Ben Shephard, A War of Nerves (London: Jonathan Cape, 2000); Elaine Showalter, The Female Malady: Women, Madness, and English Culture, 1830-1980 (New York: Pantheon Books, 1985); Martin Stone, 'Shellshock and the psychologists', in William F. Bynum, Roy Porter and Michael Shepherd (eds), The Anatomy of Madness: Essays in the History of Psychiatry, Vol. 2: Institutions and Society (London and New York: Tavistock Publications, 1985), 242-71; Ted Bogacz, 'War Neurosis and Cultural Change in England, 1914-22: The Work of the War Office Committee of Enquiry into "shell-shock" ', Journal of Contemporary History, 24, 2 (1989), 227-56.

105 Ben Shephard argued about this point, but limited his major focus on actual treatment for 'early' cases at Maghull military psychiatric hospital (Ben Shephard, 'The early treatment of mental disorders: R.G. Rows and Maghull 1914-1918', in Berrios and Freeman (eds), op. cit., Vol. 2 (note 1), 434-64).

106 WO293/4: 1-1304 (Army Council: Instructions), 1916, National Archives, Kew; WO293/5: 1308-2449 (Army Council: Instructions), 1916, National Archives, Kew.

107 William Aldren Turner, 'Arrangements for the Care of Cases of Nervous and Mental Shock Coming from Overseas', The Lancet, 187, 4839 (1916), 1073-5.

108 MH51/239: Circular Letters of the Commissioners in Lunacy, 1914-1921, National Archives, Kew. 
certifying and non-pauperising treatment for them. James Duncan Millar (1871-1932), a barrister and Liberal Member of Parliament for Lanarkshire North-East, asked the War Office "whether steps had been taken to secure that the treatment of soldiers and sailors suffering from mental strain should be carried out in hospital wards or other institutions not under lunacy administration, so as to avoid sending all such cases, which were not certifiable, to asylums'. ${ }^{109}$ 'No stigma of insanity ought to attach to them', Millar stated. ${ }^{110}$ In wartime, 38 parliamentary colleagues asked similar questions on 72 occasions, even though lunacy topics had only been mentioned several times each year before the Great War.

Due to parliamentary objections, the government could not overlook the problem of shell-shocked soldiers in lunatic asylums, and in 1917 decided to provide a special arrangement, the 'Service Patient Scheme'. ${ }^{111}$ This scheme guaranteed two special provisions for shell-shocked soldiers: first, a state pension that covered the non-pauper rate of their maintenance in asylums, and second, permission to wear a distinctive uniform and badge. ${ }^{112}$ Under this scheme, however, shell-shocked soldiers could avoid only the stigma of pauperism, not that of lunacy, because the 1890 Act did not allow psychiatric admission into lunatic asylums without legal certification.

Nevertheless, this scheme marked a significant sign for psychiatrists, as it suggested a defect in the 1890 Act: lunatic patients, whether temporary, early or otherwise, had no choice but to be legally certified for psychiatric treatment. Hence, psychiatrists discovered a rare chance for Lunacy Law reform. In January 1916, Bedford Pierce (1861-1932), medical superintendent of the York Retreat, argued for the necessity of early treatment with a new emphasis on wartime non-medical demands for non-certifying psychiatric treatment:

General public attention was called to the matter [the absence of proper facilities for treatment of nervous and mental disorder in their earlier stages], when it was realised that, apart from certification, there was no legal method of treating soldiers temporarily disordered in mind. It was at once seen that the existing procedure was impossible for men temporarily broken down in the service of their country. ${ }^{113}$

Following Pierce, doctors who had worked in the Maghull military mental hospital, namely Richard Gundry Rows (1860-1925), the medical superintendent, Grafton Elliot Smith (1871-1937), and Tom Hatherley Pear (1886-1972), argued for the application of the Service Patient Scheme to peacetime legislation. ${ }^{114}$ They all made the criticism that the 1890 Act stigmatised patients with legal certification, and thereby deterred prospective patients from accessing psychiatric treatment.

\footnotetext{
109 Parliamentary Debates, House of Commons, 69 (1915), 146.

110 Ibid., 69 (1915), 515.

111 Peter Barham has closely examined this scheme (Peter Barham, Forgotten Lunatics of the Great War (Yale University Press, 2004)).

112 MH51/694: Conference between Board of Control and Ministry of Pensions: memorandum on pensioning of 'service patients' of unsound mind, 1917, National Archives, Kew.

113 Bedford Pierce, 'An Address on the Absence of Proper Facilities for the Treatment of Mental Disorders in Their Early Stages: Delivered at a Meeting of the Yorkshire Branch of the British Medical Association', British Medical Journal, 1, 2871 (1916), 41.

114 R.G. Rows, 'Mental Conditions Following Strain and Nerve Shock', British Medical Journal, 1, 2882 (1916), 441; G. Elliott Smith and T.H. Pear, Shell Shock and its Lessons (Manchester: Manchester University Press, 1917), 81; 'Early Treatment of Mental Disorders', Journal of Mental Science, 64, 205 (1918), 213; MS4578: Medico-Psychological Association of Great Britain and Ireland: Lunacy Legislation Committee, Draft Report, 1918, Wellcome Trust Library Western Manuscripts and Archives.
} 
The post-war campaign gained wide support from The Lancet and the MedicoPsychological Association, as well as the Board of Control. ${ }^{115}$ In particular, the Board of Control played an important role in the campaign. It proposed a Lunacy Law reform with the newly established Ministry of Health, ${ }^{116}$ which submitted two amendment bills to Parliament in 1920 and $1923 .{ }^{117}$ However, Parliament once again withdrew the bills.

Psychiatrists had to wait for Labour to come into power. Before the war, they discussed psychiatric early treatment with the intention of lobbying Liberal MPs because they sympathised the most with the discourse of 'early treatment of mental disorder' that psychiatrists had related to poor law reform and national efficiency. In the age of Lloyd George's cabinet, psychiatrists had support from the Ministers of Health from the Liberal Party: Christopher Addison and Alfred Mond. ${ }^{118}$ As the Liberals started on a downward path after the war, however, psychiatrists came to rely on Labour politicians, who considered Lunacy Law reform a related issue to poor law reform in which disease, an important cause of poverty, had to be tackled with preventive measures. In particular, they involved Earl Russell, the first Labour member of the House of Lords, in Lunacy Law reform. He was a man whom Armstrong-Jones had influenced greatly. ${ }^{119}$

In 1924 the first Labour government came to power and appointed a Royal Commission on Lunacy and Mental disorder, whose ten commissioners included six politicians who were either Labour MPs or sympathisers. ${ }^{120}$ In the Commission, psychiatrists, including Maurice Craig, vigorously pursued their political claims for "early treatment of mental disorders'. The final report stated that 'the keynote of the past has been detention; the keynote of the future should be prevention and treatment', and called for 'the eradication of old-established prejudices and a complete revision of the attitudes of society in the matter of its duty to the mentally afflicted'. ${ }^{121}$ Importantly, it problematised legal certification because it carried a stigma in the public mind, causing delay in treatment. On these grounds, the Royal Commission concluded with a recommendation for psychiatric early treatment. The first Labour Cabinet, however, was overturned within a year, which disappointed psychiatrists.

\footnotetext{
115 'The Effect of the War upon Psychiatry in England', The Lancet, 190, 4905 (1917), 353; 'The Problem of the Insane Sailor and Soldier', The Lancet, 190, 4912 (1917), 612-13; 'Early Treatment of Mental Disorders', Journal of Mental Science 64, 205 (1918), 213.

${ }_{116}$ MH51/687: Reconstruction Committee: Correspondence with Board of Control on the promotion and conservation of the health of the population, 1916-17, National Archives, Kew.

${ }^{117}$ Ministry of Health (Miscellaneous Provisions) Bill, Twentieth-Century House of Commons Sessional Papers, Bills, 1920, 215; Mental Treatment Bill, Twentieth-Century House of Commons Sessional Papers, Bills, 1923, 169.

118 Parliamentary Debates, House of Commons, 172 (1920), 532; Report of the Proceedings of the Conference convened by Sir Frederick Willis, Chairman of the Board of Control between Commissioners of the Board and Medical Superintendents and Chairman of Visiting Committees of County and Borough Mental Hospitals, and Medical Superintendents and Chairmen of Managing Committees of Registered Mental Hospitals, and certain others (London: H.M.S.O., 1922), 5.

119 The third Earl Russell, John Francis Stanley Russell (1865-1931) was a grandson of Lord John Russell, Prime Minister twice between the 1840s and 1860s. He was the elder brother of Bertrand Russell. Moved by Armstrong-Jones' speech at the Medico-Legal Society in 1913, he continuously supported the amendment bill for the 1890 Act.

120 On the Labour side, there were Hugh Pattison Macmillan (1873-1952), the Lord Advocate of the Labour Government; William Allen Jowitt (1885-1957), former Labour MP temporarily losing his seat in 1924; Henry Snell (1865-1944), Labour MP; Madeleine Jane Robinson (1896-1957), a social campaigner for women workers; and Earl Russell. The medical commissioners were Humphry Davy Rolleston (1862-1944), physician and neurologist to St. George's Hospital, and David Drummond (1852-1932), Professor of Medicine of the Durham College of Medicine.

${ }^{121}$ Report of the Royal Commission on Lunacy and Mental Disorder, op. cit (note 21), 17, 18-19, 43.
} 
In 1929 the second Labour government finally delivered a new law to psychiatrists. Earl Russell introduced a bill to amend the 1890 Act in the House of Lords. ${ }^{122}$ With the support of the Ministry of Health and the Labour government, Parliament passed the 1929 bill without major opposition. In the proceedings, Arthur Greenwood (1880-1954), the Minister of Health, and Arabella Susan Lawrence (1871-1947), the Parliamentary Secretary for the Minister, represented well the recommendations of the Royal Commission on Lunacy and Mental disorder. ${ }^{123}$

On 10 July 1930, the Mental Treatment Act was finally given Royal Assent. ${ }^{124}$ The new Act won three important provisions: (1) the extension of voluntary admission into all mental health premises, including public mental hospitals and registered private nursing homes; (2) the introduction of temporary admission where psychiatric institutions could receive for six months patients who were unwilling to be admitted to mental hospitals but were supposedly curable in earlier stages of their disease; and (3) the empowerment of local authorities to establish psychiatric outpatient clinics in general hospitals. With these measures, psychiatrists legitimised their authority over treatment of incipient and milder cases without legal certification.

\section{Key Devices in 'Early Treatment of Mental Disorder'}

English psychiatrists projected professional interests into the 1930 Act, not simply intending it for humanitarian, preventive and efficient psychiatry. Professional interest comes through clearly in the content of the bills that psychiatrists proposed as an alternative to the 1890 Act. In the earlier bills submitted between 1897 and 1914, psychiatrists proposed the establishment of a new psychiatric branch in general hospitals and asylums for 'temporary and early cases' without legal certification. ${ }^{125}$ This clearly shows they expected to promote psychiatrists' consulting business. They also proposed to allow private asylums and registered hospitals to receive voluntary cases with the consent of only one Lunacy Commissioner. In so doing, they aimed to deregulate the voluntary admission that had become attractive in the post- 1890 period. Importantly, psychiatrists often proposed abolishing Section 315, the penalty clause for treatment without legal certification. Although not put in the 1930 statute, it indicates that they wished to eviscerate the 1890 Act's regulations against the commercialisation of psychiatry,

Interestingly, the Ministry of Health (Miscellaneous Provisions) Bill of 1920 met opposition from psychiatrists, although Clause 10 enabled treatment for early cases without legal certification. When it was withdrawn in Parliament, the MedicoPsychological Association stated that ' $[\mathrm{t}]$ he Association would rather have the clause dropped entirely than that it should become law without the emendation it had urged ... we would rather have no change at all than one in the wrong direction'. ${ }^{126}$ The misdirection was that Clause 10 limited treatment without legal certification to 'people who had previously been in an asylum' and 'those recent cases who were unable to give

\footnotetext{
122 Journals of the House of Commons, 185 (1930), 144.

123 Parliamentary Debates, House of Commons, 235 (1930), 957-64.

124 Mental Treatment Act, 1930, 20 \& 21 George V, ch. 23.

125 A bill intituled an act to amend the lunacy acts, Twentieth-Century House of Commons Sessional Papers, Bills, 1897, 329; A bill intituled an act to amend the lunacy acts, Twentieth-Century House of Commons Sessional Papers, Bills, 1898, 298; A bill intituled an act to amend the lunacy acts, Twentieth-Century House of Commons Sessional Papers, Bills 1899, 225; A bill intituled an act to amend the lunacy acts, TwentiethCentury House of Commons Sessional Papers, Bills 1900, 119; A bill to amend the Lunacy Acts, TwentiethCentury House of Commons Sessional Papers, Bills, 1904, 210. The 1914 bill and its contents are found only in Parliamentary Archives, probably because the proceedings were confused by the commencement of the war (HL/PO/JO/10/10/561, Parliamentary Archives, 1914).

126 'Ministry of Health (Miscellaneous Provisions) Bill', Journal of Mental Science, 67, 276 (1920), 55.
} 
consent and who should be treated if possible without being certified under the Lunacy Acts' ${ }^{127}$ In other words, it prevented psychiatrists from bringing a broader stratum of patients into early treatment. The patients who had been seen by psychiatrists and nonvolitional patients consisted of a large part of the mentally ill population. Without such cases, psychiatrists could hardly see early cases as being helpful enough to their consulting business. Hence, they opposed the 1920 Bill, and welcomed the 1929 Mental Treatment Bill that extended non-certifying treatment to non-volitional and previously admitted cases. $^{128}$

The Mental Treatment Bill of 1929 satisfied psychiatrists in two ways. ${ }^{129}$ First, it introduced temporary admission systems where legislation no longer required legal certification for non-volitional early cases. Second, it allowed 'any hospitals, nursing home or place approved' to provide early treatment for voluntary and non-volitional patients without legal certification. ${ }^{130}$ The 'approved place' meant that psychiatrists could open private premises for early cases with permission from the Board of Control. While the 1890 Act still prohibited the opening of new private asylums, the 1929 Bill enabled psychiatrists to have another kind of private institution for their trade in lunacy. The new regulation yielded professional jurisdiction to psychiatrists based on the mode of practice that they had developed since 1890.

It should be noted, however, that some psychiatrists were undoubtedly interested in preventing mental diseases in early stages, which was evident particularly in a discussion about mental hygiene, physical and mental fitness, and feeble-mindedness. ${ }^{131}$ In 'early treatment of mental disorder', pursuing professional interests in career-making and institutional management, they were indeed concerned about the therapeutic ability of psychiatry. This shows that psychiatrists were not a homogeneous profession, but one that included various groups with different interests.

\section{Conclusion}

It is clear that the profession of psychiatry did not die in early twentieth-century England. Social historian Harold Perkin once argued that the professional ideal permeated twentieth-century Britain. ${ }^{132}$ His pioneering study has been available for twenty-eight years, but scholars have noticed little about the actual paths that British professions have followed. This is particularly true of psychiatry in the twentieth century. As historians of psychiatry have concentrated on the asylum and the psychiatric profession in the nineteenth century, and later on non-asylum, non-psychiatry settings in the twentieth century, the topic of psychiatrists in the twentieth century has been largely ignored. To fill this gap in the historiography, this paper has shed light on the historical process

\footnotetext{
${ }^{127}$ Ministry of Health (Miscellaneous Provisions) Bill, Twentieth-Century House of Commons Sessional Papers, Bills, 1920, 215.

128 Nathan Raw, H.G.L. Haynes and R. Worth, 'Mental Treatment Bill, 1929: Report of the Parliamentary Committee', Journal of Mental Science, 76, 313 (1930), 324-6.

${ }^{129}$ Mental treatment Bill, Twentieth-Century House of Commons Sessional Papers, Bills, 1929-30, 107.

130 Ibid.

${ }^{131}$ Regarding mental hygiene, see Mathew Thomson, 'Mental hygiene as an international movement', in Paul Weindling (ed.), International Health Organisations and Movements, 1918-1939 (Cambridge: Cambridge University Press, 1995), 283-304; Mathew Thomson, 'Disability, psychiatry, and eugenics', in Alison Bashford and Philippa Levine (eds), The Oxford Handbook of the History of Eugenics (Oxford and New York: Oxford University Press, 2010), 116-33; Greta Jones, Social Hygiene in Twentieth-Century Britain (London: Wolfeboro, 1986).

${ }^{132}$ Harold Perkin, The Rise of Professional Society: England since 1880 (London: Routledge, 1989).
} 
of professional development in English psychiatry in the early twentieth century by employing sociological concepts proposed by Andrew Abbott.

This paper examined the Lunacy Act of 1890 and its practical disturbance to psychiatrists' career-making and institutional practices. The 1890 Act prohibited the opening of new private asylums that had previously provided a lucrative career for senior psychiatrists, which forced them to seek a new career path as psychiatric consultants. They entrenched themselves there by extending their consultation networks to general and neurological hospitals. On the other hand, the legislation introduced legal certification for private admission into lunatic asylums, which led charitable institutions for insanity into a more commercial line of institutional management, particularly through voluntary admission. These institutions promoted voluntary admission, where psychiatric patients did not require legal certification, in order to attract potential customers who avoided using lunacy hospitals because of judicial intervention, and probably resorted to competing professionals and illegal practitioners. Psychiatrists then recognised the need to make the law correspond to such practical shifts. They constructed a political claim of 'early treatment of mental disorder', referring to such publicly influential rhetoric as humanitarianism, poor law reform and national efficiency. The shell shock suffered by many in the Great War gave rise to political support for the psychiatric profession. To this end, they finally won new legislation.

Rephrasing the above summary in Abbott's conception, this paper suggests that the professional development of English psychiatry began with an external disturbance to the existing mode of practice, reconstructed the internal divisions of labour and workplace, worked out a jurisdictional claim with abstract notions for the public and finally reached a jurisdictional settlement by law.

This professional development story must be linked closely with a later history of English psychiatry, as it encountered significant changes in doctors' individual and institutional circumstances. The 1946 NHS Act and 1959 Mental Health Act introduced new orientations in psychiatry: the former limited commercial medical care, and the latter sought a policy of deinstitutionalisation, in which mental hospitals were closed gradually and multi-professional community care was organised instead. These do not indicate the end of professional development for psychiatry. The studies of other professions, such as mental health nurses, clinical psychologists and social workers, and their professional development will further improve our understanding of English psychiatry in the twentieth century. 